\title{
Investigation on thermal properties of a novel fuel blend and its
} diesel engine performance

\author{
L.Jiang, ${ }^{\mathrm{a}, \mathrm{b}, *}$, Y.D. Wang ${ }^{\mathrm{a}}$, A.P. Roskilly ${ }^{\mathrm{a}}$, X.L. Xie ${ }^{\mathrm{a}}$, Z.C. Zhang ${ }^{\mathrm{a}}$, R.Z. Wang ${ }^{\mathrm{b}}$ \\ ${ }^{a}$ Sir Joseph Swan Centre for Energy Research, Newcastle University, Newcastle NE1 7RU, UK \\ ${ }^{b}$ Institute of Refrigeration and Cryogenics, Shanghai Jiao Tong University, Shanghai, 200240, China
}

Abstract: It is widely recognized that characteristics of fuel are strongly related with engine performance

and exhaust emission. In this paper, a novel fuel blend is developed by adding carbon coated aluminium into diesel. Nanoparticles are blended with diesel in terms of different mass ratios, which are used for optimal selection. Thermo-physical properties of fuel blends are investigated at different testing temperatures. It is indicated that carbon coated aluminium is quite conducive to thermal conductivity but has little influence on viscosity. The highest thermal conductivity by using carbon coated aluminium could reach $0.23 \mathrm{~W} \cdot \mathrm{m}^{-1} \cdot \mathrm{K}^{-1}$ which is improved by $15 \%$ when compared with neat diesel. Then a series of experimental tests are conducted by using a heavy duty engine. Results show that at $1810 \mathrm{rpm}$ speed, brake specific fuel consumption is in the range from $0.1 \mathrm{~kg} \cdot \mathrm{kWh}^{-1}$ to $0.41 \mathrm{~kg} \cdot \mathrm{kWh}^{-1}$. By using carbon coated aluminium, brake specific fuel consumption could be reduced by up to $13.3 \%$. The maximum emission reduction by using novel fuel blend could reach $16.7 \%, 48.8 \%$ and $33.5 \%$ in terms of nitrogen oxides, hydrocarbon compound and carbon monoxide. Based on improved thermos-physical properties, positive effect of carbon coated aluminium on engine performance and emissions has been demonstrated.

Keywords: Diesel, Carbon coated aluminium, Engine performance, Emission

\footnotetext{
* Corresponding author. Tel. +44-05792206270

Email: Long.jiang@newcastle.ac.uk(L.Jiang)
} 
$\mathrm{Al} @ \mathrm{C}$

A

BSFC

B0

B0E4

B0E4N30

$C_{\mathrm{p}}$

$\mathrm{CO}$

$d$

E

EDX

ESC

Fe@C

$\mathrm{HC}$

$\mathrm{NO}_{\mathrm{x}}$

Ni@C

$P$

$\mathrm{R}$

SCR

$T$

TEM

$t_{50}$

22

\section{Greek letters}

$\alpha$

$\beta$

$\gamma$

$\lambda$

$\rho$
Carbon coated aluminium

Pre-experimental factor $(\mathrm{Pa} \cdot \mathrm{s})$

Brake specific fuel consumption

Diesel

Diesel with $4 \%$ ethanol

Diesel with 4\% ethanol and 30ppmAl@C

Specific heat capacity $\left(\mathrm{J} \cdot \mathrm{g}^{-1} \cdot{ }^{\circ} \mathrm{C}^{-1}\right)$

Carbon monoxide

Thickness of sample (m)

Activation energy $\left(\mathrm{kJ} \cdot \mathrm{mol}^{-1}\right)$

Energy Dispersive X-ray

European Stationary Cycle

Carbon coated iron

Hydrocarbon compound

Nitrogen oxides

Carbon coated nickel

Power (kW)

Gas constant $\left(\mathrm{J} \cdot \mathrm{mol}^{-1} \cdot \mathrm{K}^{-1}\right)$

Selective catalysts reduction

Temperature $\left({ }^{\circ} \mathrm{C}\right)$

Transmission electron microscope

Half time

Thermal diffusivity $\left(\mathrm{mm} \cdot \mathrm{s}^{-1}\right)$

Mass ratio of diesel with regard to mass of fuel blend

Mass ratio of ethanol with regard to mass of fuel blend

Thermal conductivity $\left(\mathrm{W} \cdot \mathrm{m}^{-1} \cdot \mathrm{K}^{-1}\right)$

Density $\left(\mathrm{kg} \cdot \mathrm{m}^{-3}\right)$ 


\section{Subscripts}

$\begin{array}{ll}\mathrm{Al} @ \mathrm{C} & \text { Carbon coated aluminium } \\ \mathrm{di} & \text { Diesel } \\ \text { en } & \text { Ethanol } \\ \mathrm{ex} & \text { Exhaust } \\ \mathrm{fb} & \text { Fuel blend }\end{array}$

\section{Introduction}

Since the issue of high energy consumption and environmental pollution, an increasing number of attentions has been paid to energy efficiency improvement and pollutant emission reduction in the past decades [1]. In order to decrease pollutant emission of vehicles, strict standards have been proposed and come into force all over the world [2]. To deal with this problem, renewable alternative fuels [3], engine modification [4] and exhaust gas treatment e.g. selective catalysts reduction (SCR) [5] are characterized as main methods. Considering cost and feasibility, alternative fuels still take a leading role since it could reduce pollutant emissions with relatively small impact on engine performance [6].

A variety of researches on alternative fuels have been widely investigated. The blended renewable biofuels remarkable fact is that alcohol has potentials to be adopted as oxygenated fuel additives for fossil-based fuels, which could control soot emissions $[8,9]$. Among alcoholic additives, methanol is the most oxygenated, which may increase the amount of nitrogen oxides $\left(\mathrm{NO}_{\mathrm{x}}\right)$ under some operation conditions due to the increase of oxygen content in fuel [10]. Ethanol is known as a renewable fuel, which is often used as an additive in clean fuel blends 
compound $(\mathrm{HC})$ and $\mathrm{NO}_{\mathrm{x}}$ emission are determined by different mass ratios $[12,13]$. Butanol could be added to diesel fuel without incorporating other additives due to high cetane number and great molecular weight of nbutanol [14]. Moreover, a two-phase composition does not form in case of blending with diesel fuel at any temperature. Compared with the alcoholic additive, other vegetable oils e.g. sunflower oil [15], coconut oil [16] and bio diesel [17] are attempted to be added to the oil-based fuels for diesel engines. Nevertheless, when blending the oxygenated fuels with diesel fuels, the basic fuel properties e.g. density, flash point, viscosity and cetane number may be varied, which may have an influence on engine performance [18]. Emission reduction and engine power are required to be balanced when alcohol is added to diesel for an optimal selection. Under this scenario, fuel blends are often jointly used with tertiary additives e.g. nitro methane, methyl ester and octyl nitrate $[19,20]$. Despite various advantages e.g. preventing formation of a two-phase blend and viscosity enhancement, tertiary additives inevitably result in the increase of brake specific fuel consumption (BSFC) and the decrease of brake power [21]. To overcome these disadvantages, nanoparticles are selected as alternative additives to improve thermo-physical properties, e.g. diffusivity, viscosity and thermal conductivity [22]. The most commonly used nanoparticles are composed of ceramics and metal oxides, e.g. zinc oxide, titanium oxide, cerium oxide and carbon nanotubes as additives $[23,24]$. Metal oxides are generally able to improve chemical reaction process while carbon based materials could enhance heat transfer performance [23, 25]. Combining advantages of these additives may be more desirable to further improve engine performance with less pollutant emissions. Thus carbon coated metal with core-shell structure reveals vast potentials in developing novel fuel blends. Carbon coating is able to protect the external condition for the metal core, and the metal core can take a promoting effect while maintaining the excellent thermo-physical properties in the working process [26]. One striking fact is that carbon coated metal has been successfully applied into chemical sorbents for sorption thermal energy storage, which accelerates the chemisorption reaction process [27, 28]. It is expected to have a positive effect on fuel blends due to the fact that 
thermal conductivity and lipophilicity could be improved which is superior to that using metal oxide and carbon based material, respectively. Combustion inside engine is then more complete, and emissions of $\mathrm{NO}_{\mathrm{x}}, \mathrm{HC}$ and $\mathrm{CO}$ will be reduced to some extents.

Less research is reported for fuel blends by using carbon coated metal as additive. The objective of this paper is to demonstrate the positive effect of carbon coated aluminium on neat fuel. The improved thermo-physical properties result in an efficient engine performance and cleaner emissions. Thus the overarching framework of this paper could be elaborated as follows: novel fuel blends are first developed by using Al@C with different mass ratios. Thermo-physical properties of fuel blends using Al@C i.e. thermal diffusivity, thermal conductivity and viscosity are then tested and compared with that not using Al@C. Based on thermo-physical properties of fuel blends, performance is analysed in terms of BSFC, exhaust temperature, $\mathrm{NO}_{\mathrm{x}}, \mathrm{HC}$ and $\mathrm{CO}$ emission.

\section{Materials}

\subsection{Carbon coated metal}

As a type of nanoparticles, carbon coated metal is characterized with core-shell structure. Metal core is protected by carbon coating as external condition for maintaining its excellent properties inside. The commonly used metal cores are $\mathrm{Al}, \mathrm{Ni}, \mathrm{Fe}$ and $\mathrm{Cu}$ which could play different roles. $\mathrm{Al} @ \mathrm{C}$ is selected as an example for illustrating their similar structures. Fig.1 indicates transmission electron microscope (TEM) image of Al@C with different magnitudes, which could refer to our previous work [29]. The encapsulated structure of Al@C is observed. It is worth noting that aluminium cores are completely surrounded by carbon shells with a thickness ranging from $2 \mathrm{~nm}$ to $4 \mathrm{~nm}$. Core-shell structure of nanoparticles with metallic core and carbon shell could protect metal core due to the fact that carbon based materials have a high thermal stability even in severe conditions. Also carbon shell could improve suspension stability of the nanoparticle when it is dispersed in fuel since metal tends be hydrophilic. 


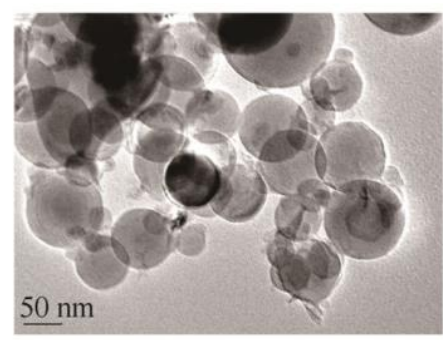

(a)

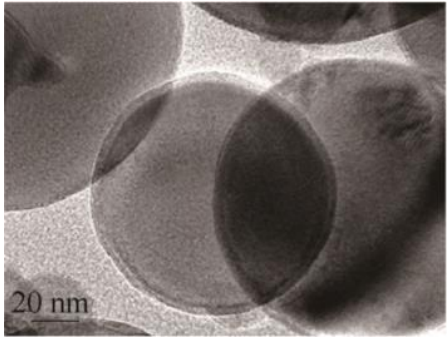

(b)

Fig.1 TEM image of Al@C with different magnitudes (a) 50 nm; (b) 20 nm [29].

\subsection{Preparation of novel fuel blends}

The detailed developing processes of novel fuel blend by using carbon coated metal is indicated in Fig.2, which are described as follows: carbon coated metal is first mixed with ethanol as surfactant in ultrasonic bath for 2 hours (a1 process). This process aims to disperse the aggregated particle and have a good distribution in surfactant. Simultaneously, diesel is measured as a set volume (a2 process). Then the mixture will be combined with diesel in ultrasonic bath for 30 minutes (b process). After that, fuel blends become darker, which indicates homogeneously distribution in diesel (c process). Finally, fuel blends will be poured into small bottles for observing their precipitation (d process).

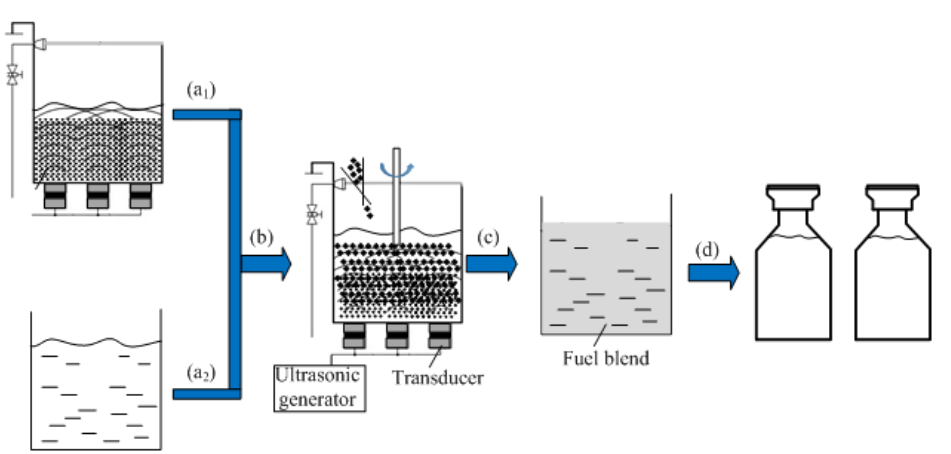

Fig.2 Developing processes of novel fuel blends by using carbon coated metal.

Other carbon coated metals e.g. carbon coated nickel $(\mathrm{Ni} @ \mathrm{C})$ and carbon coated iron (Fe@C) tend to precipitate after one night, which are not suitable for developing fuel blends. Difference of fuel blends by using Al@C and other carbon coated metals is probably related with Van der Waals force between nanoparticles and oil molecules. Van der Waals force of Al@C is stronger than its gravity whereas other carbon coated metals have a stronger gravity than their van der Waals force [30]. That is the main reason for selecting Al@C as fuel additive 


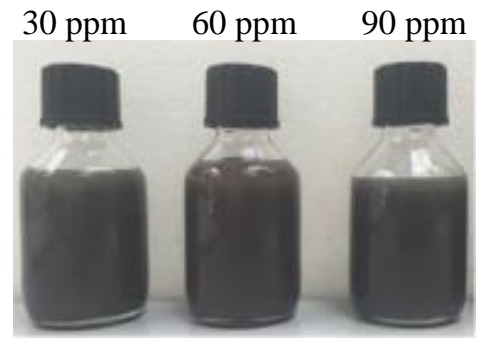

(a)

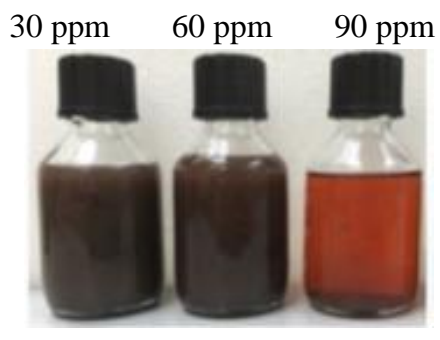

(b)

Fig.3 Comparison of fuel blends with various mass ratios of $\mathrm{Al} @ \mathrm{C}$ (a) just finished; b) two weeks later.

114

in this paper. Different mass ratios of $\mathrm{Al} @$ C, i.e. 30 ppm, 60 ppm and 90 ppm are selected for further comparison which are shown in Fig.3. It is demonstrated that sample with a ratio of $30 \mathrm{ppm}$ remains stable during two weeks whereas sample with 60 ppm precipitates partially on the bottom of the bottle. Comparably, sample with 90 ppm shows a significant deposit. Phase separation becomes obvious with the increase of mass ratio of Al@C due to the fact there is a weak gel structure of nanoparticles in ethanol. This structure results in a strong van der Waals force for particles in suspension. Thus fuel blend with 30 ppm of $\mathrm{Al} @ \mathrm{C}$ is selected for testing thermos-physical properties and engine performance in the rest of this paper, which is compared with that without using Al@C. The detailed parameters of fuel blends are shown in Table 1.

Table 1 Fuel blends developed for testing thermo-physical properties and diesel engine.

\begin{tabular}{cc}
\hline Fuel blends & Specific composition \\
\hline B0 & $100 \%$ Diesel \\
B0E4 & $100 \%$ Diesel \& 4\% Ethanol \\
B0E4N30 & $100 \%$ Diesel \& 4\% Ethanol \& 30 ppm Al@C
\end{tabular}

\section{Thermo-physical properties testing}

Thermal conductivity of fuel blend is investigated by laser flash method, and the concerning testing equipment, i.e. LFA467 instrument. Structure and testing procedures of the unit could refer to the reference [31]. The testing temperature is monitored by means of an infrared detector, which is first calibrated by liquid nitrogen. Thermal diffusivity could be determined through the curve of temperature vs. time. Sample holder for liquids is specially used in the experiment which is shown in Fig.4. The liquid is filled into the holder by using syringe and then the hole is blocked by locking pins. 

dimensional heat transfer process. Thermal diffusivity could be evaluated by equation 1 :

$$
\alpha=0.1388 \cdot d^{2} / t_{50}
$$

where $\alpha$ is thermal diffusivity $\left(\mathrm{mm}^{2} \cdot \mathrm{s}^{-1}\right), d$ is thickness of the testing sample $(\mathrm{mm}), t_{50}$ is semi-heating time (s).

Thermal conductivity could then be calculated by equation 2 :

$$
\lambda=\rho(T) \cdot C_{\mathrm{p}}(T) \cdot \alpha(T)
$$

where $\lambda(T)$ is thermal conductivity at a testing temperature $\left(\mathrm{W} \cdot \mathrm{m}^{-1} \cdot \mathrm{K}^{-1}\right), \alpha(T)$ is thermal diffusivity $\left(\mathrm{mm}^{2} \cdot \mathrm{s}^{-1}\right), C_{\mathrm{p}}$ is specific heat $\left(\mathrm{J} \cdot \mathrm{g}^{-1} \cdot \mathrm{K}^{-1}\right), \rho(T)$ is density of the sample $\left(\mathrm{kg} \cdot \mathrm{m}^{-3}\right)$. The random error of the testing equipment is less than $0.1 \%$, and the largest relative error of thermal conductivity is $5 \%$.

Specific heat and density of novel fuel blends are calculated by equation 3 and 4 , which are according to

their respective mass ratios of mixture.

$$
\begin{aligned}
\rho_{\mathrm{fb}} & =\beta \cdot \rho_{\mathrm{p}, \mathrm{di}}+\gamma \cdot \rho_{\mathrm{p}, \mathrm{en}}+(1-\beta-\gamma) \cdot \rho_{\mathrm{p}, \mathrm{Al} @ \mathrm{C}} \\
C_{\mathrm{p}, \mathrm{fb}} & =\beta \cdot C_{\mathrm{p}, \mathrm{di}}+\gamma \cdot C_{\mathrm{p}, \mathrm{en}}+(1-\beta-\gamma) \cdot C_{\mathrm{p}, \mathrm{Al} @ \mathrm{C}}
\end{aligned}
$$

where $\beta$ is mass ratio of diesel with respect to total mass of novel fuel blend, $\gamma$ is mass ratio of ethanol with respect to total mass.

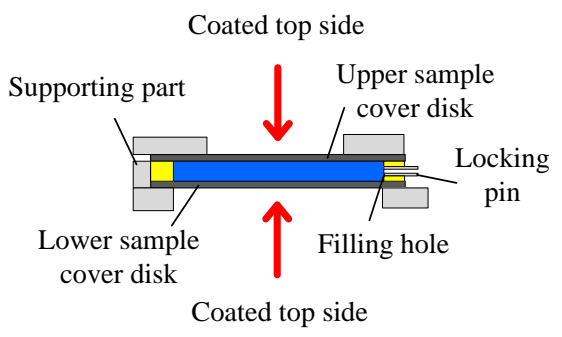

(a)

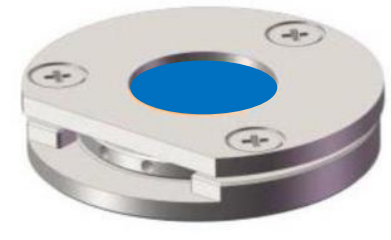

(b)

Fig.4 Sample holder for low-viscous liquid (a) schematic; (b) photo.

Before testing thermal properties of fuel blends, thermal diffusivity of pure water is first tested which is compared with the corresponding literature value for calibration as shown in Fig.5. The reference result of water is $0.147 \mathrm{~mm}^{2} \cdot \mathrm{s}^{-1}$ at $30^{\circ} \mathrm{C}$. The relative error is no more than $3 \%$, which is within acceptable range. It is demonstrated 

blends.

$$
\sigma^{\prime}=\sqrt{\frac{\sum_{1}^{n}(x-\mu)^{2}}{N}}
$$

that laser flash method is suitable to be applied for testing thermal diffusivity of fuel blends. The standard error is also calculated according to equation 5. The error bars are added in the rest of paper. Fig. 6 shows thermal diffusivity of fuel blends when testing temperature varies from $25^{\circ} \mathrm{C}$ to $90^{\circ} \mathrm{C}$. It is worth noting that thermal diffusivities of different fuel blends increase with the increase of testing temperature. Thermal diffusivity of $\mathrm{B} 0 \mathrm{E} 4 \mathrm{~N} 30$ is higher than that of B0 and B0E4. B0E4 has a similar thermal diffusivity with B0, which indicates that $4 \%$ ethanol almost has no influence on thermal diffusivity. The highest thermal diffusivity of B0E4N30 could reach $0.161 \mathrm{~mm}^{2} \cdot \mathrm{s}^{-1}$ at $25^{\circ} \mathrm{C}$, which is $18 \%$ higher than that of $\mathrm{B} 0$. For different fuel blends, thermal diffusivity is in the range between $0.081 \mathrm{~mm}^{2} \cdot \mathrm{s}^{-1}$ and $0.161 \mathrm{~mm}^{2} \cdot \mathrm{s}^{-1}$ when temperature ranges from $25^{\circ} \mathrm{C}$ to $90^{\circ} \mathrm{C}$. Based on thermal diffusivity, thermal conductivities of various fuel blends are then calculated which are shown in Fig.7. According to equation 3 and 4, specific heat capacity and density are also combined results of diesel, ethanol and Al@C. Due to the largest mass ratio, diesel still takes a leading role. Density decreases with the increase of temperature whereas specific heat increases with the increase temperature. The decrease of density of diesel is around $-0.0017 \mathrm{~g} \cdot \mathrm{cm}^{-3}$ per Celsius whereas increment of specific heat is around $0.0037 \mathrm{~J} \cdot \mathrm{g}^{-1} \cdot{ }^{\circ} \mathrm{C}^{-1}$. Similar with trend of thermal diffusivity, thermal conductivities of fuel blends increase with the increase of testing temperature. Thermal conductivity of B0E4N30 is higher than that of other two, but the difference becomes close with the increase of testing temperature. It is indicated that ethanol also has little influence on thermal conductivity of fuel blends. With the increase of temperature, thermal conductivity of B0 is almost the same with B0E4. This could be attributed to small mass ratio and limited higher thermal conductivity of ethanol e.g. $0.126 \mathrm{~W} \cdot \mathrm{m}^{-1} \cdot \mathrm{K}^{-1}$ for $\mathrm{B} 0$ and $0.16 \mathrm{~W} \cdot \mathrm{m}^{-1} \cdot \mathrm{K}^{-1}$ for ethanol at environmental temperature. Comparably, Al@C strongly enhances thermal conductivity due to its unique characteristic. The highest thermal conductivity of B0E4N30 could reach $0.23 \mathrm{~W} \cdot \mathrm{m}^{-}$ ${ }^{1} \cdot \mathrm{K}^{-1}$ at $90^{\circ} \mathrm{C}$ testing temperature which is improved by $15 \%$ when compared with $\mathrm{B} 0$. With temperature increasing from $25^{\circ} \mathrm{C}$ to $90^{\circ} \mathrm{C}$, thermal conductivity ranges from $0.124 \mathrm{~W} \cdot \mathrm{m}^{-1} \cdot \mathrm{K}^{-1}$ to $0.23 \mathrm{~W} \cdot \mathrm{m}^{-1} \cdot \mathrm{K}^{-1}$ in terms of different fuel 


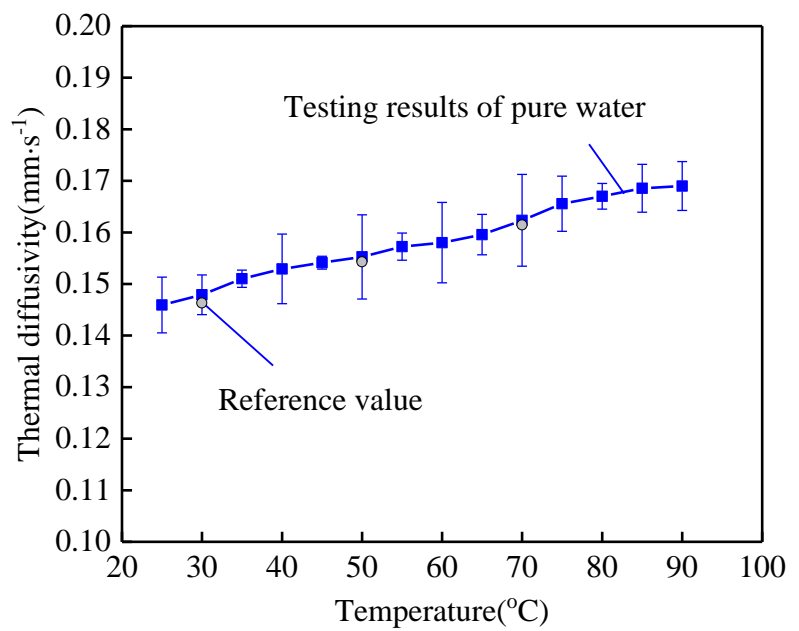

Fig.5 Thermal diffusivity of pure water vs. different testing temperatures.

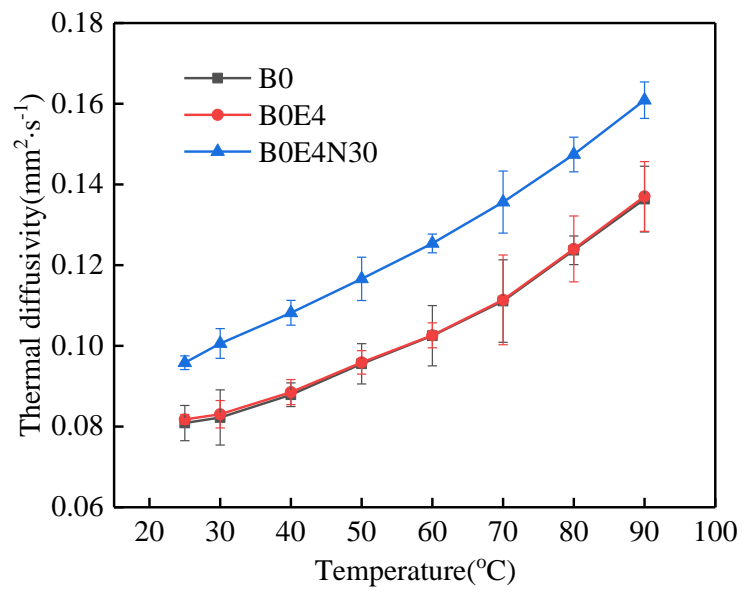

Fig.6 Thermal diffusivity of fuel blends vs. different testing temperatures.

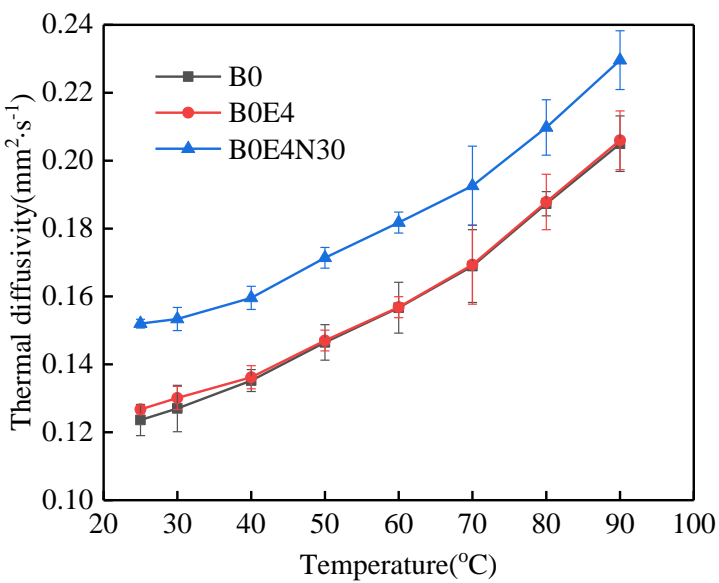

Fig.7 Thermal conductivity of fuel blends vs. different testing temperatures. 
Viscosities of oleic acid are also tested at different temperatures by a viscometer, which are shown in Fig.8. Results show that viscosities of different fuel blends are quite close. B0 has a relatively high viscosity than the other two when temperature increases from $25^{\circ} \mathrm{C}$ to $75^{\circ} \mathrm{C}$. Viscosity of $\mathrm{B} 0 \mathrm{E} 4$ is a bit higher than that of B0E4N30 with temperature ranging from $25^{\circ} \mathrm{C}$ to $40^{\circ} \mathrm{C}$ whereas almost no difference could be observed when temperature is higher than $40^{\circ} \mathrm{C}$. With regard to viscosities of fuel blends, ethanol has a more positive influence than that of Al@C.Al@C could further improve the viscosity of B0E4 in low temperature range. When testing temperature increases from $25^{\circ} \mathrm{C}$ to $75^{\circ} \mathrm{C}$, dynamic viscosity decreases from $3.67 \mathrm{mPa} \cdot \mathrm{s}$ to $1.062 \mathrm{mPa} \cdot \mathrm{s}$ in terms of different fuel blends. In order to comprehensively analyse the performance of viscosity, Arrhenius relationship is used to correlate the viscosity with different testing temperatures as shown in equation 6 [32]. It could be transformed and linearly fitted by equation 7 . Then activation energy and pre-experimental factor of fuel blends are obtained as indicated in Table 2. Results demonstrate that B0 has the highest activation energy and the lowest pre-experimental factor whereas B0E4N30 reveals the reverse results. It is generally acknowledged that activation energy is within $15-30 \mathrm{~kJ} \cdot \mathrm{mol}^{-1}$ and natural logarithm of pre-experimental factor ranges from $-17 \mathrm{~Pa} \cdot \mathrm{s}$ to $-10 \mathrm{~Pa} \cdot \mathrm{s}$ in terms of low and moderate viscous fluids. Thus the fitting results of testing viscosity are in a reasonable range, and average absolute deviation of dynamic viscosity is no more than $5 \%$ when compared with ideal value calculated by each pure material according to Eyring equation [33].

$$
\mu=A \cdot \exp (E / R T)
$$

where $E$ is activation energy, $A$ is pre-experimental factor of fuel blends.

$$
\operatorname{Ln} \mu=\operatorname{Ln} A+E / R T
$$

Table 2 Activation energy and pre-experimental factor of fuel blends.

\begin{tabular}{ccc}
\hline Fuel blends & $\operatorname{Ln}(\mathrm{A})(\mathrm{Pa} \cdot \mathrm{s})$ & $\mathrm{E}\left(\mathrm{kJ} \cdot \mathrm{mol}^{-1}\right)$ \\
\hline B0 & -14.577 & 21.35 \\
B0E4 & -14.234 & 21.29 \\
B0E4N30 & -14.156 & 21.05 \\
\hline
\end{tabular}




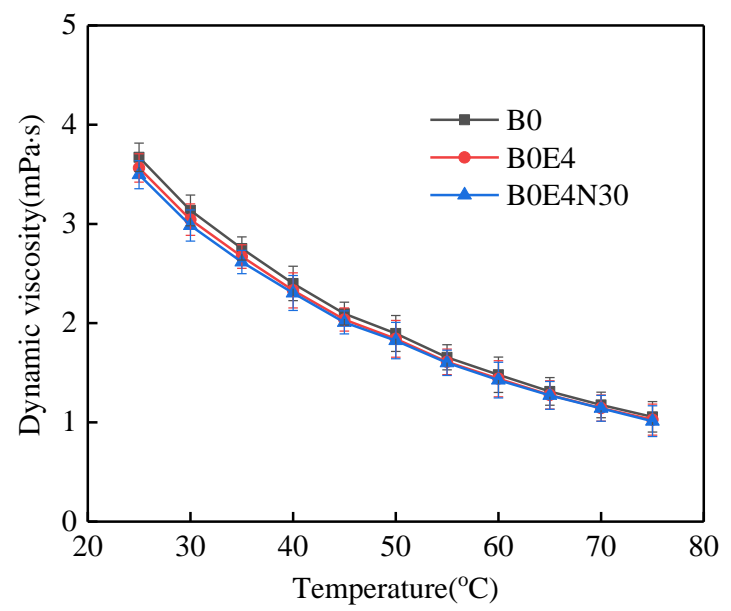

Fig.8 Viscosity of fuel blends vs different testing temperatures.

\section{Diesel engine testing}

Fig.9 indicates diesel engine bench for fuel and exhaust testing, and its schematic and photo are presented in Fig.9a and Fig.9b, respectively. The diesel engine bench is mainly composed of a diesel engine, an oil tank, a dynamometer, an intercooler, an air flow meter, a turbo charger and exhaust gas analysers. A heavy-duty diesel engine is adopted for testing which is produced by Cummins, and detailed information is indicated as in Table 3.

212 A common rail fuel injection system has four solenoid injectors for each cylinder with a maximum pressure of 1800 bar. Through intake system and fuel control system, fuel enters the combustion chamber of diesel engine. Exhaust turbocharger and intercooler are also equipped in the intake and exhaust system to control flowrate and temperature during the combustion process. Eddy current dynamometer is able to achieve multipoint of choice and control. Testing apparatus with their accuracies is listed in Table 4. All exhausts are measured and assessed by HORIBA MEXA 1600D gas analyser. The rest of this part is relevant to engine performance and emissions, and more details could refer to our previous work [34]. 


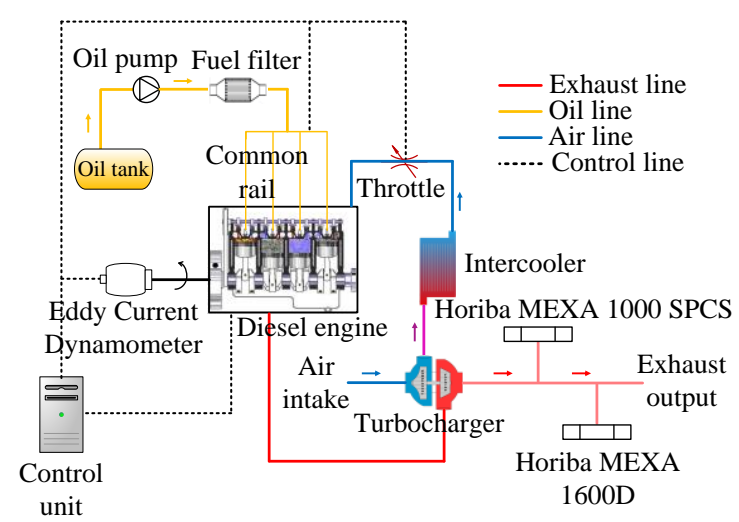

(a)

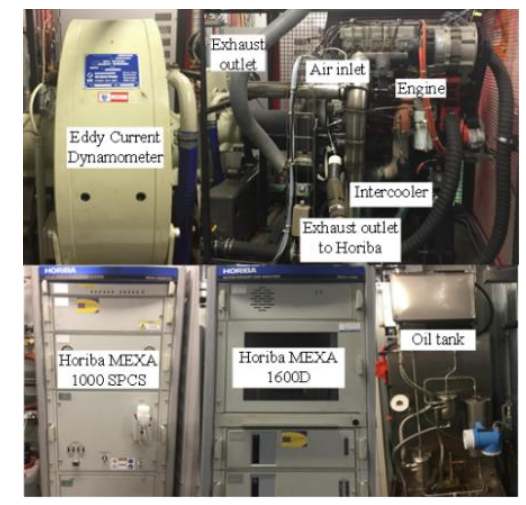

(b)

Fig.9 Diagram of engine test bench (a) schematic; (b) photo [35].

Table 3 Specification of diesel engine ISBe 5.

\begin{tabular}{cc}
\hline Specification & Explanation \\
\hline Cylinder & 4 \\
Chamber & $\omega$ type \\
Peak torque & $760 \mathrm{~N} \cdot \mathrm{m}$ \\
Displacement & $4.5 \mathrm{~L}$ \\
Governed speed & $2500 \mathrm{rpm}$ \\
Stroke & $124 \mathrm{~mm}$ \\
Bore & $107 \mathrm{~mm}$ \\
Compression ratio & 17.3 \\
Emission standard & Euro V \\
\hline
\end{tabular}

Table 4 The main testing apparatus for testing bench.

\begin{tabular}{cccc}
\hline Apparatus & Type & Testing scope & Accuracy \\
\hline Dynamometer & Eddy current & $0-230 \mathrm{~kW}$ & $\pm 0.3 \mathrm{R}$ \\
Temperature sensor & $\mathrm{K}$ & $0-1200^{\circ} \mathrm{C}$ & $\pm 0.1^{\circ} \mathrm{C}$ \\
Pressure sensors & PTX & $0-10 \mathrm{bar}$ & $\pm 0.1 \%$ \\
HORIBA & 1600D & $0-500 \mathrm{~g} \cdot \mathrm{kW}^{-1} \cdot \mathrm{h}^{-1}$ & $\pm 0.2 \%$ \\
\hline
\end{tabular}

Fig.10 demonstrates engine exhaust temperature of different fuel blends at a fixed speed of $1810 \mathrm{rpm}$. Under

227 this scenario, operation load of engine corresponds with the power, e.g. $25 \%$ load accounts for $32 \mathrm{~kW}$ while $100 \%$

228 load accounts for $119.4 \mathrm{~kW}$. Results show that diesel exhaust temperature increases with the increase of the load.

229 The highest exhaust temperature could reach $614^{\circ} \mathrm{C}$ at $100 \%$ load. When load increases from $25 \%$ to $100 \%$, exhaust 
temperature ranges from $321^{\circ} \mathrm{C}$ to $614^{\circ} \mathrm{C}$ by using different fuel blends. One remarkable fact is that addition of Al@C could reduce engine exhaust temperature. The exhaust temperature of engine by using B0E4 is lower than that of B0. This is mainly because ethanol has a lower energy density and a higher enthalpy of vaporization than diesel. Also exhaust temperature by using B0E4N30 is lower than the other two fuels without using Al@C due to the improved thermal diffusivity and reduced viscosity. When compared with exhaust temperature of B0, average reduction is about 4.3\%, in which 1.8\% and 2.5\% come from ethanol and Al@C, respectively. Also worth noting that engine combustion performance is improved when exhaust temperature is reduced. The more complete combustion is achieved, the less engine energy is consumed, which improves combustion reaction of fuel and thermal efficiency.

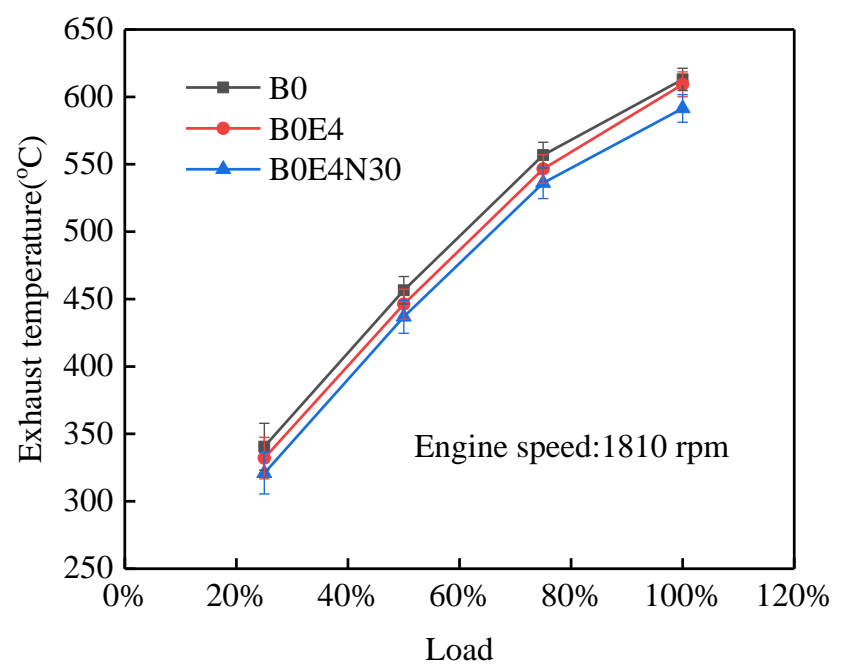

Fig.10 Exhaust temperature by using three fuel blends vs different operation loads.

Brake specific fuel consumption (BSFC) is a significant parameter for assessing engine performance. It is generally acknowledged that the desirable BFSC of heavy-duty diesel engine is about $200 \mathrm{~g} \cdot \mathrm{kWh}^{-1}$ [36]. Fig.11 demonstrates experimental BSFC by using different fuel blends. At engine speed of $1810 \mathrm{rpm}$, BSFC decreases with the increase of the load, and the results are in the range from $0.1 \mathrm{~kg} \cdot \mathrm{kWh}^{-1}$ to $0.41 \mathrm{~kg} \cdot \mathrm{kWh}^{-1}$. Similar with exhaust temperature, $\mathrm{Al} @ \mathrm{C}$ has a positive influence on improving fuel economy of the engine. BSFC of B0E4N30 is always lower than that of B0 at different loads. When the load is higher than $25 \%$, BSFC of B0E4 is higher than that of B0, which reveals that adding ethanol to diesel is not conducive to BSFC. This is mainly because ethanol has a relatively low energy density which results in more fuel consumptions at a same load. Comparably, BSFC of B0E4N30 is reduced by up to $16.8 \%$ when compared with B0E4. Also the gap between these two fuel blends 
becomes large with the increase of load due to the fact that fuel-air mixture in the cylinder is more homogeneous when thermal diffusivity of fuel blend is higher, which results in more complete combustion.

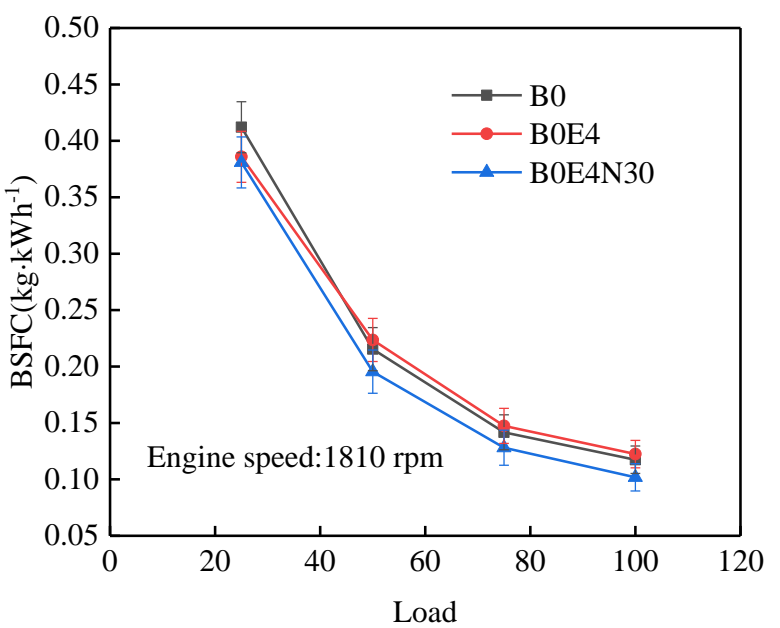

Fig.11 BSFC by using three fuel blends vs different operation loads.

Fig.12 demonstrates specific emissions of engine by using different fuel blends in terms of $\mathrm{NO}_{\mathrm{x}}, \mathrm{HC}$ and $\mathrm{CO}$, which are shown in Fig.12a, Fig.12b and Fig.12c, respectively. The results are converted into specific value according to equation 8 to 10 , and standard error at various loads are also presented.

Considering $\mathrm{NO}_{\mathrm{x}}$ emission, it is demonstrated that the specific results decrease with the increase of load due to the reduced fuel consumption. $\mathrm{NO}_{\mathrm{x}}$ emission of $\mathrm{B} 0 \mathrm{E} 4$ at $25 \%$ load becomes a bit higher when compared with B0. When load is higher than $25 \%, \mathrm{NO}_{\mathrm{x}}$ emission of $\mathrm{B} 0 \mathrm{E} 4$ is slightly lower than that of $\mathrm{B} 0$ due to the relatively low combustion temperature of ethanol. Also emission characteristic by using B0E4N30 is similar to B0E4 within the low-load range. However, when load is higher than 25\%, $\mathrm{Al} @ \mathrm{C}$ is quite conducive to $\mathrm{NO}_{\mathrm{x}}$ emission which is reduced by up to $16.8 \%$ in comparison with $\mathrm{B} 0$ due to the improved heat transfer performance. The highest $\mathrm{NO}_{\mathrm{x}}$ emission could reach $14.7 \mathrm{~g} \cdot \mathrm{kWh}^{-1}$ by using B0E4 whereas B0E4N30 reveals the lowest $\mathrm{NO}_{\mathrm{x}}$ emission of 3.52 $\mathrm{g} \cdot \mathrm{kWh}^{-1}$ in terms of different loads. The reasons are elaborated as follow: It is widely acknowledged that $\mathrm{NO}_{\mathrm{x}}$ emission is mainly determined by combustion temperature. Fuel blend by mixing Al@C has the lowest combustion temperature, which results in the least $\mathrm{NO}_{\mathrm{x}}$ emission.

In regard of $\mathrm{HC}$ emission, it could be observed that specific $\mathrm{HC}$ emission also decreases with the increase of load. HC emissions from B0E4 and B0E4N30 are higher than those from B0 under low load conditions, because the in-cylinder temperature is not quite high at low load and existence of ethanol contributes to lower combustion 
temperature, which promotes HC production. However, with the increase of load, HC emission of B0E4 surpasses that of B0E4N30 and becomes almost the same with B0. This is mainly because the in-cylinder temperature is much higher at high load and the effect of ethanol becomes ignorable. Moreover, $\mathrm{Al} @ \mathrm{C}$ is demonstrated to reduce $\mathrm{HC}$ emission at most engine operation loads because it can promote the oxidation of HC. The reason that B0E4N30 produces slightly higher HC than B0 at low load is that the effect of ethanol exceeds that of Al@C.

CO emissions from B0E4 and B0E4N30 are significantly lower than those from B0 at 25\% load. The effect of ethanol on reducing $\mathrm{CO}$ emissions is mainly caused by oxygen in its molecule which can oxidise $\mathrm{CO}$ generated during combustion. In contrast, $\mathrm{Al} @ \mathrm{C}$ is more likely to accelerate the reaction rate of combustion and produce less CO. With the increase of the load, $\mathrm{CO}$ emissions from B0E4 are almost the same as those of B0 whereas $\mathrm{CO}$ emissions by using B0E4N30 are relatively lower than the other two. This could be mainly attributed to the role of $\mathrm{Al} @ \mathrm{C}$. CO emission of B0E4N30 could be reduced by up to 33.5\% when compared with B0 due to the better combustion.

It is recognised that $\mathrm{Al} @ \mathrm{C}$ as an oxidation catalyst leads to a higher heat transfer rate, promoting complete combustion that reduces the emission levels of $\mathrm{NO}_{\mathrm{x}}, \mathrm{HC}$ and $\mathrm{CO}$. At low loads, the emissions are quite low, which reduce the effect of nanoparticles or even have a negative influence. This could be observed from error bars, which are overlapped partially. At high loads, effect of Al@C becomes obvious and almost no overlapping happens. It is demonstrated that large surface contact area of $\mathrm{Al} @ \mathrm{C}$ increases chemical reactivity, which consecutively shortens the ignition delay. Fuel-air mixing and uniform burning are improved. Also worth noting that fuel atomization is improved due to a higher thermal diffusivity, which brings about complete combustion.

$$
\begin{aligned}
s N O_{\mathrm{x}} & =0.001587 \cdot N O_{\mathrm{x}}(\mathrm{ppm}) \cdot m_{e x} / P \\
s H C & =0.000478 \cdot H C(\mathrm{ppm}) \cdot m_{e x} / P \\
s C O & =0.000966 \cdot C O(\mathrm{ppm}) \cdot m_{e x} / P
\end{aligned}
$$




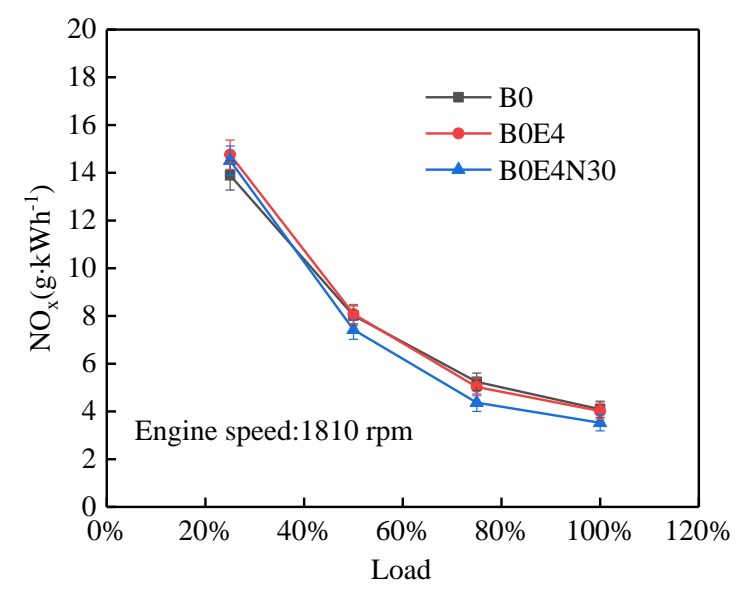

(a)

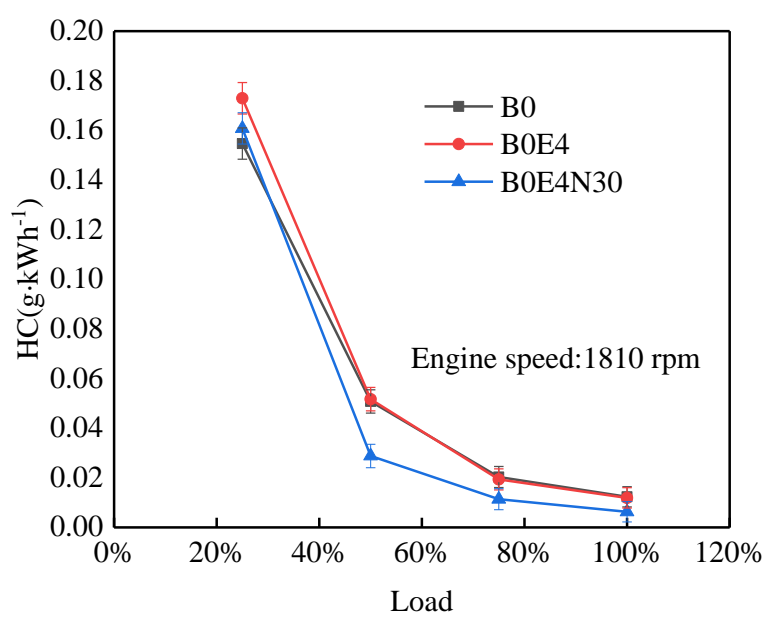

(b)

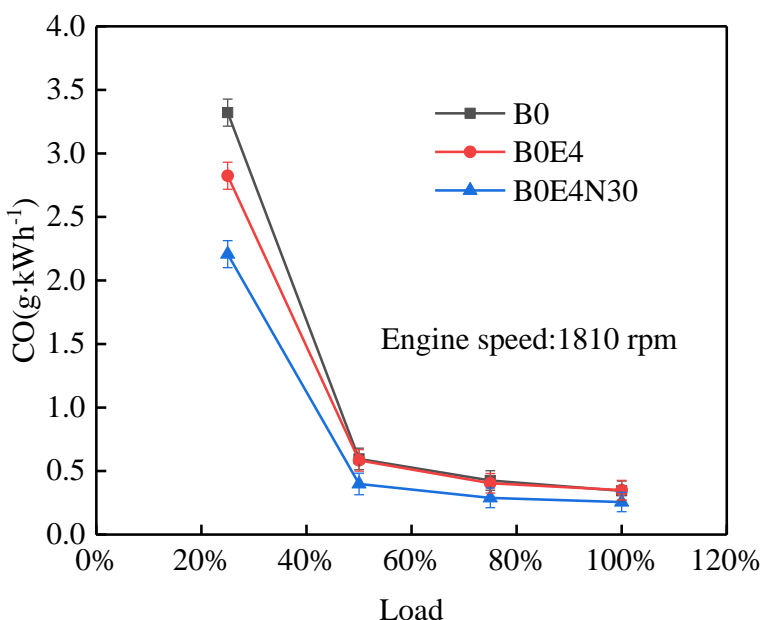

(c)

Fig.12 Specific emissions by using three fuel blends vs different operation loads (a) $\mathrm{NO}_{\mathrm{x}}$; (b) $\mathrm{HC}$; (c) CO. 

conducted to measure engine performance and pollutant emissions at Euro 5 stage [37]. Different testing modes are divided into four groups from low loads to high loads. Average BSFCs and emissions in ESC testing modes are compared between B0E4 and B0E4N30, which mainly aims to analyze the effect of $\mathrm{Al} @ \mathrm{C}$. It is worth noting that $\mathrm{Al} @ \mathrm{C}$ is advantageous to BSFC in all operation modes. Under full load condition, BSFC of B0E4N30 is reduced by about $15.7 \%$ when compared with that of $\mathrm{B} 0 \mathrm{E} 4$. Also worth noting that $\mathrm{NO}_{\mathrm{x}}$ reduction caused by $\mathrm{Al} @ \mathrm{C}$ could reach up to $16.6 \%$. As for $\mathrm{HC}$ emission, a large reduction could be obtained by individual effect of thermal diffusivity by using $\mathrm{Al} @ \mathrm{C}$ indicates the even distribution of fuel in the combustion chamber, i.e. mixture with too rich or low concentration is avoided, and reaction could be accelerated with more oxygen. The average reduction of $\mathrm{HC}$ emission by using $\mathrm{Al} @ \mathrm{C}$ reaches $22.7 \%$. Similar with $\mathrm{HC}$ emission, B0E4N30 has a lower CO emission than the B0E4 which could be attributed to the fact that reaction could proceed with more oxygen for complete combustion. When considering the testing errors, the reductions at high loads i.e. above $25 \%$ still could reach up to $18 \%$ within the confidence interval. and emission. The more details e.g. testing procedures and methods could be refer to our previous work [38]. Fig.13 compares energy dispersive x-ray (EDX) results before and after combustion. It is indicated that combustion residues contain the elements of copper, aluminium, oxygen, carbon and silicon. Compared with values of $\mathrm{Al} @ \mathrm{C}$ carbon, it is demonstrated that aluminium atoms exist in the form of oxide rather than metal after combustion. 
Al@C nanoparticles have been transformed into alumina particle during combustion process in engine. And this

transition may have a positive impact on both engine performance and emissions. With higher diffusivity and viscosity, atomisation is also improved by using $\mathrm{Al} @ \mathrm{C}$. When fuel blend is injected into the combustion chamber, nanoparticles are dispersed homogeneously and react with the oxygen predominately to form alumina and $\mathrm{CO}_{2}$.

Some of these reactions surpass that forming nitrogen with oxygen during the combustion process.

Table 5. Comparison of BSFC and engine emissions in ESC testing modes.

\begin{tabular}{cccccc}
\hline \multirow{2}{*}{ Load\% } & Mode & \multicolumn{5}{c}{ B0E4N30 vs. B0E4 (\%) } \\
\cline { 3 - 6 } & & BSFC & NO $_{\mathrm{x}}$ emission & HC emission & CO emission \\
\hline 25 & $6,8,10$ & -4 & -3.8 & -10.2 & -20.7 \\
50 & $2,4,12$ & -6.9 & -3.9 & -20.1 & -20.7 \\
75 & $3,5,11$ & -12.4 & -10.5 & -26.2 & -20.1 \\
100 & $1,7,9$ & -15.7 & -16.6 & -34.4 & -24 \\
\hline
\end{tabular}

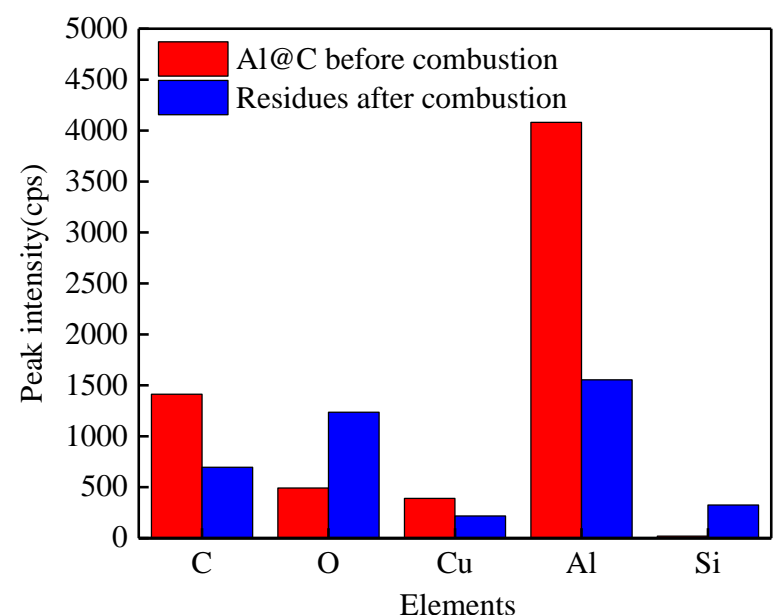

Fig.13 EDX results before and after combustion.

\section{Conclusions}

A novel fuel blend is developed by adding Al@C into diesel. Nanoparticles are adopted with diesel in terms of different mass ratios for optimal selection. Thermo-physical properties of fuel blends are investigated at different 
testing temperatures. Based on testing properties of fuel blends, performance is analysed in terms of exhaust temperature, $\mathrm{BSFC}, \mathrm{NO}_{\mathrm{x}}, \mathrm{HC}$ and $\mathrm{CO}$ emission. Conclusions are yielded as follows:

[1] Thermal diffusivities of different fuel blends increase with the increase of testing temperature. Thermal diffusivity of B0E4N30 is higher than that of B0 and B0E4. The highest thermal diffusivity of B0E4N30 could reach $0.161 \mathrm{~mm}^{2} \cdot \mathrm{s}^{-1}$, which is $18 \%$ higher than that of B0. Thermal conductivity of B0 is also higher than that of other two, but their difference becomes close with the increase of testing temperature. When temperature increases from $25^{\circ} \mathrm{C}$ to $90^{\circ} \mathrm{C}$, thermal conductivity ranges from $0.124 \mathrm{~W} \cdot \mathrm{m}^{-1} \cdot \mathrm{K}^{-1}$ to $0.23 \mathrm{~W} \cdot \mathrm{m}^{-1} \cdot \mathrm{K}^{-1}$.

[2] Viscosities of different fuel blends are quite close. B0 has a relatively high viscosity than the other two. Ethanol has a positive influence on B0 whereas $\mathrm{Al} @ \mathrm{C}$ has no impact on fuel blends. When testing temperature increases from $25^{\circ} \mathrm{C}$ to $75^{\circ} \mathrm{C}$, dynamic viscosity decreases from $3.67 \mathrm{mPa} \cdot \mathrm{s}$ to $1.062 \mathrm{mPa} \cdot \mathrm{s}$ in terms of different fuel blends. B0 has the highest activation energy and the lowest pre-experimental factor whereas B0E4N30 reveals the reverse results.

[3] At $1810 \mathrm{rpm}$ speed, BSFC decreases with the increase of the load, and the results range from 0.1 $\mathrm{kg} \cdot \mathrm{kWh}^{-1}$ to $0.41 \mathrm{~kg} \cdot \mathrm{kWh}^{-1}$. BSFC of B0E4 is higher than that of B0E4N30 when the load is higher than 25\%. Specific emissions i.e. $\mathrm{NO}_{\mathrm{x}}, \mathrm{HC}$ and $\mathrm{CO}$ decrease with the increase of load. $\mathrm{NO}_{\mathrm{x}}$ emission by using B0E4N30 is similar with B0E4 at 25\% load. When load is higher than $25 \%, \mathrm{NO}_{\mathrm{x}}$ emissions by using B0E4N30 is reduced by up to $16.8 \%$ in comparison with B0. When the load increases from $25 \%$ to $100 \%$, $\mathrm{HC}$ emission of $\mathrm{B} 0 \mathrm{E} 4 \mathrm{~N} 30$ is reduced by up to $48.8 \%$ in comparison with $\mathrm{B} 0$. CO emission of B0E4N30 could be reduced by up to $33.5 \%$ when compared with B0.

The proposed novel fuel blend by using Al@C may be an alternative approach in the near future, which is quite conducive to engine performance and emission. Ethanol has a positive influence on $\mathrm{NO}_{\mathrm{x}}$ emission while its effects on BSFC, HC and CO emission are not always obvious. It is desirable to seek for another surfactant, which may further improve overall performance. Or try to develop fuel blends without using surfactant by other methods e.g. long-term ultrasonic. 


\section{Acknowledgements}

This research was supported by National Natural Science Foundation of China under contract number (51606118), Innovative Research Groups under contract number (51521004) and Heat-STRESS project (EP/N02155X/1) funded by Engineering and Physical Science Research Council of the UK.

\section{References}

[1] Zhang Z, E J, Deng Y, Pham M, Zuo W, Peng Q, et al. Effects of fatty acid methyl esters proportion on

[2] Zannis TC, Pariotis EG, Hountalas DT, Rakopoulos DC, Levendis YA. Theoretical study of DI diesel engine performance and pollutant emissions using comparable air-side and fuel-side oxygen addition. Energy Conversion and Management. 2007;48(11):2962-70. renewable alternative energy source for diesel engine. Energy Conversion and Management. 2017;139:110-21.

[4] Taghavifar H, Khalilarya S, Jafarmadar S. Engine structure modifications effect on the flow behavior,

C):1077-85. 
391

392

393

[7] Imdadul HK, Masjuki HH, Kalam MA, Zulkifli NWM, Alabdulkarem A, Rashed MM, et al. Influences of ignition improver additive on ternary (diesel-biodiesel-higher alcohol) blends thermal stability and diesel engine performance. Energy Conversion and Management. 2016;123:252-64.

[8] da Silva Trindade WR, dos Santos RG. 1D modeling of SI engine using n-butanol as fuel: Adjust of fuel properties and comparison between measurements and simulation. Energy Conversion and Management. 2018;157:224-38.

[9] Chen L, Zhang Z, Lu Y, Zhang C, Zhang X, Zhang C, et al. Experimental study of the gaseous and particulate matter emissions from a gas turbine combustor burning butyl butyrate and ethanol blends. Applied Energy. 2017;195:693-701.

[10] Soukht Saraee H, Taghavifar H, Jafarmadar S. Experimental and numerical consideration of the effect of $\mathrm{CeO}_{2}$ nanoparticles on diesel engine performance and exhaust emission with the aid of artificial neural network. Applied Thermal Engineering. 2017;113:663-72.

[11] Chen L, Stone R, Richardson D. A study of mixture preparation and PM emissions using a direct injection engine fuelled with stoichiometric gasoline/ethanol blends. Fuel. 2012;96:120-30.

[12] Kwanchareon P, Luengnaruemitchai A, Jai-In S. Solubility of a diesel-biodiesel-ethanol blend, its fuel properties, and its emission characteristics from diesel engine. Fuel. 2007;86(7):1053-61.

[13] Li D-g, Zhen H, Xingcai L, Wu-gao Z, Jian-guang Y. Physico-chemical properties of ethanol-diesel blend fuel and its effect on performance and emissions of diesel engines. Renewable Energy. 2005;30(6):967-76.

[14] Su T, Ji C, Wang S, Cong X, Shi L, Yang J. Improving the lean performance of an n-butanol rotary engine by hydrogen enrichment. Energy Conversion and Management. 2018;157:96-102.

[15] Shehata MS, Razek SMA. Experimental investigation of diesel engine performance and emission characteristics using jojoba/diesel blend and sunflower oil. Fuel. 2011;90(2):886-97. 
413

414

415

[16] Machacon HTC, Shiga S, Karasawa T, Nakamura H. Performance and emission characteristics of a diesel engine fueled with coconut oil-diesel fuel blend. Biomass and Bioenergy. 2001;20(1):63-9.

[17] Balat M, Balat H. A critical review of bio-diesel as a vehicular fuel. Energy Conversion and Management. 2008;49(10):2727-41.

[18] An H, Yang WM, Li J, Zhou DZ. Modeling study of oxygenated fuels on diesel combustion: Effects of oxygen concentration, cetane number and C/H ratio. Energy Conversion and Management. 2015;90:261-71.

[19] Fayyazbakhsh A, Pirouzfar V. Comprehensive overview on diesel additives to reduce emissions, enhance fuel properties and improve engine performance. Renewable and Sustainable Energy Reviews. 2017;74:891-901.

[20] Sivakumar M, Shanmuga Sundaram N, Ramesh kumar R, Syed Thasthagir MH. Effect of aluminium oxide nanoparticles blended pongamia methyl ester on performance, combustion and emission characteristics of diesel engine. Renewable Energy. 2018;116:518-26.

[21] Imdadul HK, Rashed MM, Shahin MM, Masjuki HH, Kalam MA, Kamruzzaman M, et al. Quality improvement of biodiesel blends using different promising fuel additives to reduce fuel consumption and NO emission from CI engine. Energy Conversion and Management. 2017;138:327-37.

[22] Annamalai M, Dhinesh B, Nanthagopal K, SivaramaKrishnan P, Isaac JoshuaRamesh Lalvani J, Parthasarathy M, et al. An assessment on performance, combustion and emission behavior of a diesel engine powered by ceria nanoparticle blended emulsified biofuel. Energy Conversion and Management. 2016;123:372-80.

[23] Nanthagopal K, Ashok B, Tamilarasu A, Johny A, Mohan A. Influence on the effect of zinc oxide and titanium dioxide nanoparticles as an additive with Calophyllum inophyllum methyl ester in a CI engine. Energy Conversion and Management. 2017;146:8-19.

[24] Laad M, Jatti VKS. Titanium oxide nanoparticles as additives in engine oil. Journal of King Saud University - Engineering Sciences. 2016. 
[25] Mardhiah HH, Ong HC, Masjuki HH, Lim S, Pang YL. Investigation of carbon-based solid acid catalyst from Jatropha curcas biomass in biodiesel production. Energy Conversion and Management. 2017;144:10-7.

[26] Jiang L, Wang RZ, Lu YJ, Roskilly AP, Wang LW, Tang K. Investigation on novel modular sorption thermal cell with improved energy charging and discharging performance. Energy Conversion and Management. 2017;148:110-9.

[27] Jiang L, Lu YJ, Tang K, Wang YD, Wang R, Roskilly AP, et al. Investigation on heat and mass transfer performance of novel composite strontium chloride for sorption reactors. Applied Thermal Engineering. 2017;121:410-8.

[28] Jiang L, Roskilly AP, Wang RZ, Wang LW, Lu YJ. Analysis on innovative modular sorption and resorption thermal cell for cold and heat cogeneration. Applied Energy. 2017;204:767-79.

[29] Wu Q, Yu X, Zhang H, Chen Y, Liu L, Xie X, et al. Fabrication and thermal conductivity improvement of novel composite adsorbents adding with nanoparticles. Chinese journal of mechanical engineering. 2016;6:11148.

[30] Eastman JA, Phillpot SR, Choi SUS, Keblinski P. Thermal Transport in Nanofluids1. Annual Review of Materials Research. 2004;34(1):219-46.

[31] Jiang L, Wang LW, Wang RZ. Investigation on thermal conductive consolidated composite $\mathrm{CaCl} 2$ for adsorption refrigeration. International Journal of Thermal Sciences. 2014;81:68-75.

[32] Soto F, Alves M, Valdés JC, Armas O, Crnkovic P, Rodrigues G, et al. The determination of the activation energy of diesel and biodiesel fuels and the analysis of engine performance and soot emissions. Fuel Processing Technology. 2018;174:69-77.

[33] Franco Z, Nguyen QD. Flow properties of vegetable oil-diesel fuel blends. Fuel. 2011;90(2):838-43.

[34] Xie XL. Investigation on performance and emission for a heavy duty diesel engine with nano-aluminium 

to reduce nitrogen oxides of diesel engine by using carbon nanoparticle. Applied Thermal Engineering. 2018;134:29-38.

461 [36] Solouk A, Shakiba-Herfeh M, Arora J, Shahbakhti M. Fuel consumption assessment of an electrified powertrain with a multi-mode high-efficiency engine in various levels of hybridization. Energy Conversion and Management. 2018;155:100-15.

[37] Nabi MN, Zare A, Hossain FM, Bodisco TA, Ristovski ZD, Brown RJ. A parametric study on engine performance and emissions with neat diesel and diesel-butanol blends in the 13-Mode European Stationary Cycle. Energy Conversion and Management. 2017;148:251-9.

[38] Wu Q, Xie X, Wang Y, Roskilly T. Effect of carbon coated aluminum nanoparticles as additive to biodiesel- 